\title{
Ingested hyaluronan moisturizes dry skin
}

\author{
Chinatsu Kawada', Takushi Yoshida ${ }^{1}$, Hideto Yoshida ${ }^{1}$, Ryosuke Matsuoka ${ }^{1 *}$, Wakako Sakamoto ${ }^{1}$, Wataru Odanaka ${ }^{1}$, \\ Toshihide Sato', Takeshi Yamasaki ${ }^{1}$, Tomoyuki Kanemitsu', Yasunobu Masuda ${ }^{1}$ and Osamu Urushibata²
}

\begin{abstract}
Hyaluronan $(\mathrm{HA})$ is present in many tissues of the body and is essential to maintain moistness in the skin tissues, which contain approximately half the body's HA mass. Due to its viscosity and moisturizing effect, HA is widely distributed as a medicine, cosmetic, food, and, recently marketed in Japan as a popular dietary supplement to promote skin moisture. In a randomized, double-blind, placebo-controlled clinical study it was found that ingested HA increased skin moisture and improved treatment outcomes for patients with dry skin. HA is also reported to be absorbed by the body distributed, in part, to the skin. Ingested HA contributes to the increased synthesis of HA and promotes cell proliferation in fibroblasts. These effects show that ingestion of HA moisturizes the skin and is expected to improve the quality of life for people who suffer from dry skin. This review examines the moisturizing effects of dry skin by ingested HA and summarizes the series of mechanisms from absorption to pharmacological action.
\end{abstract}

Keywords: Hyaluronan, Hyaluronic acid, Ingestion, Dry skin, Moisturizing

\section{Introduction}

In 1934, Meyer et al. [1] isolated and identified hyaluronan (HA), also called hyaluronic acid, from the vitreous humor of a cow's eyes. HA is a macromolecular mucopolysaccharide that is widely distributed in body tissues and intracellular fluids, and it is present at high concentrations in the synovial fluid, vitreous humor, and skin [2]. Because HA is highly viscous and retains moisture, it is responsible for facilitating smooth movement of the knee joint, and maintains the normal shape of the vitreous humor and moisturizes the skin. However, aging and extrinsic stimuli such as solar ultraviolet radiation, smoking, and air pollutants gradually reduces the amount of HA in the body [3-5]. The reduction of HA in the body increase joint pain and dry skin; however, it decreases skin tension. In recent years, the public has started to ingest HA to compensate for its loss in the body. Ingested HA reduces joint pain in the knees of patients with knee osteoarthritis [6,7]. Furthermore, HA dietary supplements are expected to be effective anti-aging supplements because an American ABC News program, which aired in November 2002, stated that the key to longevity in a specific Japanese village was their HA-rich diet [8].

\footnotetext{
* Correspondence: ryosuke_matsuoka@kewpie.co.jp

${ }^{1}$ R\&D Division, Kewpie Corporation, 2-5-7, Sengawa-cho, Chofu-shi, Tokyo, Japan Full list of author information is available at the end of the article
}

Dry skin is not only caused by the hereditary factors but also by reduction of age-related decrease in intracellular lipid and naturally moisturizing factors such as free amino acids and specific salts in the stratum corneum $[9,10]$. In addition, the disturbance of the skin barrier by extrinsic stimuli such as a sudden change in the weather $[11,12]$ and contact with chemical agents also induces dry skin $[13,14]$. Estimating the number of dry skin patients in Japan is difficult because several individuals with dry skin only visit the hospital when their symptoms are severe. However, several products and supplements for dry skin are sold in Japan, suggesting that many Japanese people seek treatment for their dry skin. Individuals with dry skin experience itching because the sensory nerves in the lower layer of the skin are directly subjected to the external stimuli by the collapsing skin barrier function. Dry skin decreases a person's quality of life because of the discomfort associated with tight and dry skin. Topical moisturizers treat dry skin; however, the elderly and individuals living alone need assistance for applying the moisturizers because they cannot reach their backs. Thus, the improvement of dry skin by ingested HA is considered meaningful for those people.

Several Japanese studies have reported that ingested HA moisturizes dry skin [15-20]; however, these effects are rarely studied outside of Japan because only local researchers have access to this information. The use of 
HA as a dietary supplement is also relatively new compared with that of other nutrients used to treat dry skin; thus, the reports that examined the effects of ingested HA on the skin were compiled in this review to promote those studies. These studies elucidate the effects of ingested HA. Furthermore, HA can be utilized as a food constituent in the treatment of patients with dry skin.

This review discusses the efficacy of ingested HA in treating dry skin and identifies its mechanism of action.

\section{Hyaluronan}

HA, a linear glycosaminoglycan is a major component of the extracellular matrix that is composed of repeating polymeric disaccharides of D-glucuronic acid and N-acetylD-glucosamine linked via alternating $\beta-1,4$ and $\beta-1,3$ glycosidic bonds [21] (Figure 1). HA exists in all vertebrates and in parts of microorganisms. In particular, more than $50 \%$ of total body $\mathrm{HA}$ is present in the skin of all vertebrates [22,23]. HA in the skin is synthesized by hyaluronan synthases (HAS) in epidermal keratinocytes and dermal fibroblasts $[24,25]$. The HA content of the dermis is far greater than that of the epidermis [26]; however, its function in the epidermis has not been elucidated. Previous studies reported that HA is closely involved in keratinocyte proliferation and differentiation [27-29] and may participate in epidermal structure and turnover. In the dermis, HA is responsible for regulating water balance and maintaining the cell structure by utilizing its high water retention and viscosity [30]. These facts suggest that $\mathrm{HA}$ is an important substance that maintains a healthy skin.

\section{Applications of hyaluronan}

HA is typically used in medication, cosmetics, and food. Industrial applications use different molecular weights (MWs) of HA, which are divided into two broad categories on the basis of the method of HA preparation. These 2 categories are the chicken comb-derived HA and the HA derived from microbial fermentation. In recent years, increased mass production and the inexpensive cost of manufacturing has shifted HA production toward microbial fermentation.

Because the physical properties and physiological activities of HA differ depending on its MW [31], different

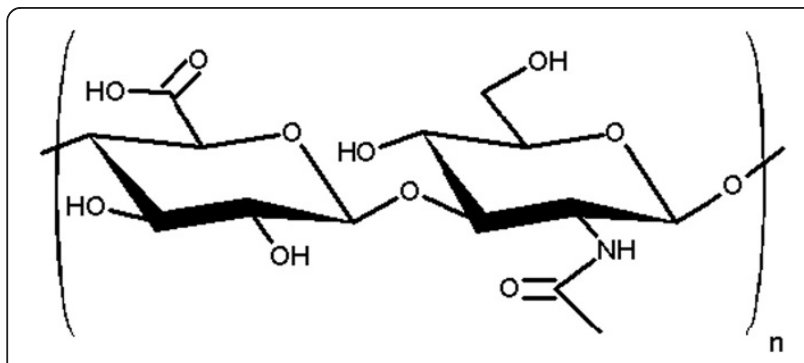

Figure 1 The structure of hyaluronan.
MW products of HA, ranging from thousands to millions, are produced. In the field of medicine, high MW HA (approximately millions) is utilized to treat degenerative joint conditions because it has high viscosity and water retention; furthermore, it is used as an adjuvant treatment in cataract surgery [32-34]. Recently, as a treatment for facial lines and wrinkles, HA fillers in cosmetic surgery were used in the world. In the field of cosmetics, the proper MW of HA was selected from a wide range of MW (from hundreds of thousands to millions), which was determined by the type of cosmetic product. HA was formulated in a toner or an emulsion lotion depending on the intended use of the product. HA had a MW of millions or less, when it was formulated with common food such as bread and salad dressing.

In 1960, the first medication using HA was formulated; in 1979, the first cosmetic product using HA was manufactured. HA was sold as a food in 1942; thus, HA was used as a food long before it was used in medication or cosmetics. Endre Balazs applied for a patent in 1942 to commercially use HA as a substitute for egg whites in bakery products [35]. Since then, HA has been included in a variety of processed foods because of its physical and water retention properties [36,37].

People in Western Europe and China considered chicken combs, which contain a lot of HA, as an imperial cuisine. Further, Yang Guifei in China and Princess Catherine, the wife of King Henry II in medieval France, believed that if they ate chicken combs they would become beautiful. Even now, HA is ingested as a dietary supplement because it is expected to improve the skin and knee joints [8]. HA is approved as a food additive in Japan and Korea and as a health food in Korea. The United States of America, Canada, Italy and Belgium sell HA as a dietary supplement; however, in the United States, individuals consume HA to improve the health of their knee joints but the effects of HA on the skin are not well-known. The Japanese know that consuming HA improves skin health and knee joint pain; thus, the Japanese population spends approximately 250 million USD per year in 2012. These facts reveal that HA is widely used as a dietary supplement in Japan [38].

\section{Ingesting hyaluronan moisturizes the skin}

Several studies have shown that ingested HA effects the knee joints [6,7] and the skin [15-20] (Table 1). In a randomized, double-blind, placebo-controlled study, human subjects that had chronically rough and dry skin (the average age \pm S.E.; $26.7 \pm 6.6$ ) received $240 \mathrm{mg} /$ day of HA (Hyaluronsan HA-F; MW $8 \times 105$, Kewpie Co., Tokyon $=11$ ) for 6 weeks. Four evaluation phases by a dermatologist determined that the conditions of dry skin in face and whole body were significantly improved in the HA group respectively compared with the placebo group 
Table 1 Summary on the skin improving effects of ingested hyaluronan

\begin{tabular}{|c|c|c|c|c|c|}
\hline Test method & Test design & Substance & Subjects & Results & References \\
\hline \multirow{2}{*}{$\begin{array}{l}\text { Oral consumption of } \\
\text { HA at } 240 \text { mg daily } \\
\text { for } 6 \text { weeks }\end{array}$} & \multirow[t]{2}{*}{$\begin{array}{l}\text { Randomized, double-blind, } \\
\text { placebo-controlled trial }\end{array}$} & \multirow[t]{2}{*}{ HA (M.W:: $80 \mathrm{~K})$} & \multirow[t]{2}{*}{$\begin{array}{l}22 \text { patients with dry skin } \\
\text { (in Japan) }\end{array}$} & $\begin{array}{l}\text { Improved dry skin on } \\
\text { the face and whole body }\end{array}$ & \multirow[t]{2}{*}{$\begin{array}{l}\text { Kajimoto, O. } \\
\text { et al. (2001) [15] }\end{array}$} \\
\hline & & & & $\begin{array}{l}\text { Significant increase } \\
\text { of skin moisture }\end{array}$ & \\
\hline $\begin{array}{l}\text { Oral consumption of } \\
\mathrm{HA} \text { at } 120 \mathrm{mg} \text { daily } \\
\text { for } 4 \text { weeks }\end{array}$ & $\begin{array}{l}\text { Randomized, double-blind, } \\
\text { placebo-controlled trial }\end{array}$ & HA (M.W.: $80 \mathrm{~K})$ & $\begin{array}{l}35 \text { patients with dry skin } \\
\text { (in Japan) }\end{array}$ & $\begin{array}{l}\text { Significant increase } \\
\text { of skin moisture }\end{array}$ & $\begin{array}{l}\text { Sato, T. et al. } \\
(2002)[16]\end{array}$ \\
\hline $\begin{array}{l}\text { Oral consumption of } \\
\text { HA at } 120 \text { mg daily } \\
\text { for } 6 \text { weeks }\end{array}$ & $\begin{array}{l}\text { Randomized, double-blind, } \\
\text { placebo-controlled trial }\end{array}$ & HA (M.W:: $80 \mathrm{~K})$ & $\begin{array}{l}39 \text { female patients with } \\
\text { dry skin (in Japan) }\end{array}$ & $\begin{array}{l}\text { Significant increase } \\
\text { of skin moisture }\end{array}$ & $\begin{array}{l}\text { Sato, T. et al. } \\
\text { (2007) [17] }\end{array}$ \\
\hline $\begin{array}{l}\text { Oral consumption of } \\
\text { HA at } 120 \text { mg daily } \\
\text { for } 6 \text { weeks }\end{array}$ & $\begin{array}{l}\text { Randomized, double-blind, } \\
\text { placebo-controlled trial }\end{array}$ & HA (M.W.: $30 \mathrm{~K})$ & $\begin{array}{l}42 \text { female patients with } \\
\text { dry skin (in Japan) }\end{array}$ & $\begin{array}{l}\text { Significant increase } \\
\text { of skin moisture }\end{array}$ & $\begin{array}{l}\text { Yoshida, T. et al. } \\
\text { (2009) [18] }\end{array}$ \\
\hline \multirow{2}{*}{$\begin{array}{l}\text { Oral consumption of } \\
\mathrm{HA} \text { at } 37.52 \mathrm{mg} \text { daily } \\
\text { for } 30 \text { days }\end{array}$} & \multirow[t]{2}{*}{$\begin{array}{l}\text { Randomized, single-blind, } \\
\text { placebo-controlled trial }\end{array}$} & \multirow{2}{*}{$\begin{array}{c}\text { Mixture containing } \\
\text { HA (M.W. of HA: } \\
2,500)\end{array}$} & \multirow[t]{2}{*}{$\begin{array}{l}107 \text { healthy subjects } \\
\text { (in China) }\end{array}$} & $\begin{array}{l}\text { Significant increase } \\
\text { in skin moisture }\end{array}$ & \multirow[t]{2}{*}{$\begin{array}{l}\text { Terashita, T. et al } \\
\text { (2011) [19] }\end{array}$} \\
\hline & & & & $\begin{array}{l}\text { Significant increase } \\
\text { in skin } \mathrm{pH}\end{array}$ & \\
\hline $\begin{array}{l}\text { Oral consumption of } \\
\text { HA at } 100 \text { mg daily } \\
\text { for } 12 \text { weeks }\end{array}$ & $\begin{array}{c}\text { Prospective } \\
\text { open-label trial }\end{array}$ & $\begin{array}{l}\text { Mixture containing } \\
\text { HA(M.W.: unknown) }\end{array}$ & $\begin{array}{c}26 \text { healthy female subjects } \\
\text { (Caucasian, African-American, } \\
\text { Hispanic, and others) }\end{array}$ & $\begin{array}{l}\text { Improved aging } \\
\text { symptoms on the face }\end{array}$ & $\begin{array}{l}\text { Schwartz, S. R. } \\
\text { et al. (2012) [20] }\end{array}$ \\
\hline
\end{tabular}

after 3 weeks and 6 weeks of ingestion. In addition, skin moisture content at the lower left part of the eye significantly improved in the HA group from 3 weeks to 6 weeks of ingestion, and skin smoothness in left of the upper arm and back of neck was significantly improved after 3 and 6 weeks of ingestion prior to the study [15]. Increases in skin moisture and improvements in skin condition in the placebo group were not confirmed compared with prior to its ingestion [15]. Further, 240 and $120 \mathrm{mg} /$ day of HA ingestion revealed that these 2 doses had equivalent effects on the skin. Namely, a daily HA dose of $120 \mathrm{mg}(\mathrm{n}=17)$ significantly increased skin moisture in the lower left part of the eye compared with a daily placebo dose $(n=18)$ 2 weeks after HA was consumed in a randomized, doubleblind, placebo-controlled study for subjects with dry skin (average age \pm S.E; $31.5 \pm 13.3$ ) [16]

Because aging is associated with a decrease of HA in the skin [3-5], a randomized, double-blind, placebo-controlled study of middle-aged and elderly female subjects with dry skin (average age \pm S.E.; $43.6 \pm 4.6$ ) was conducted [17] The HA group $(\mathrm{n}=19)$, which ingested $120 \mathrm{mg} /$ day of HA, was found to have a significant increase of skin moisture, and a tendency for the skin moisture to increase in the face, compared with the placebo group $(n=20)$ after 3 and 6 weeks of ingestion (Figure 2) [17]. These reports show that consuming either 120 or $240 \mathrm{mg} /$ day of HA contributes to increased skin moisture and improves dry skin. Thus, the lowest recommended dose of HA ingestion is $120 \mathrm{mg}$ per day.

The aforementioned studies show that consuming HA derived from chicken combs moisturizes the skin. A report has revealed that consuming HA manufactured by fermentation also moisturizes the skin [18]. In a randomized, double-blind, placebo-controlled study, female subjects with dry skin (average age \pm S.E; $43.3 \pm 4.6$ ) received $120 \mathrm{mg} /$ day of HA (Hyabest ${ }^{\circ}(\mathrm{S})$ LF-P: MW $3 \times 10^{5}$, Kewpie Co., Tokyo, $n=20)$, or placebo $(n=22)$, for 6 weeks. The HA group had better skin moisture than the placebo group during the ingestion period. Furthermore, two weeks after HA ingestion, the HA group showed significant improvement in skin moisture compared with

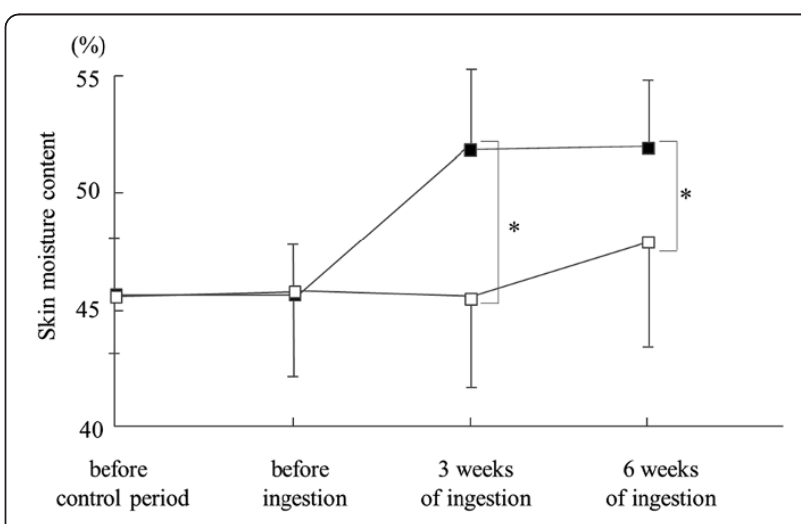

Figure 2 Skin moisture content changes by HA (MW: $8 \times 10^{5}$ ) ingestion or placebo. 39 female subjects were randomly divided into two groups (HA group, $n=19$; placebo group, $n=20$ ) to minimize the inter-group differences in skin moisture content, skin elasticity and age. The skin moisture content at the lower part of the left eye was measured using a Corneometer ${ }^{\oplus} \mathrm{CM} 825$ before the control period, before the ingestion, and after 3 and 6 weeks of the ingestion. indicates HA; $\square$ indicates placebo. An unpaired $t$-test was used to compare the two groups. Data are presented as mean \pm S.E. Asterisks indicate a statistically significant difference, ${ }^{*} p<0.05$. 
the placebo-controlled group (Figure 3) [18]. Because the skin's turnover rate normally requires 28 days to complete, the effects of the ingested HA to the stratum corneum continued for 2 weeks after treatment. Thus, these results suggest that consuming HA moisturizes the skin for several weeks after the treatment has ended.

Dry skin is induced by a variety of factors. The reports summarized in this review reveal that consuming HA improves dry skin by increasing the skin's moisture content. In addition, the skin-moisturizing effect of ingested HA is not dependent on the source or specific molecular size of the HA ingested.

There are morphological and characteristic differences in skin types among different races. In the skin of the white race, the stratum corneum is thicker and the amount of the sebum cutaneum is less than that of the black and the yellow races. The dermic layer in black and yellow races is thicker than that in the white race. The amount of sebum cutaneum increases with rising environmental temperatures [39] and this reveals that climate affects skin type. The aforementioned studies do not account for the different skin types or the environmental effects on the skin. Thus, there is some possibility that the skin-moisturizing effects of ingested HA is different according to the race of subjects or the climatic environment where they live.

In a study of non-Japanese subjects, dietary intake of chicken comb enzymatic decomposer containing HA (W-HA; mean M.W.: 2,500, Will Search Co. Ltd., Yokohama, Japan) $280 \mathrm{mg}$ per day for 30 days significantly increased skin moisture and $\mathrm{pH}$ in a placebo-controlled single-blind clinical trial in the People's Republic of China [19]. A pilot open-label study in 26 healthy females, including Caucasians and individuals of African and Hispanic descent, was carried out using chicken sternal articular cartilage hydrolyzed extract, BioCell Collagen ${ }^{\bullet}$ (BCC; BioCell Technology, LLC Newport Beach, CA), containing $100 \mathrm{mg}$ of low-molecular-weight HA [20]. Daily supplementation with $1 \mathrm{~g}$ of BioCell Collagen ${ }^{\oplus}$ for 12 weeks led to a significant reduction of skin dryness and wrinkles, and a significant increase in the content of hemoglobin and collagen in the skin dermis. However, the quality of these trials is compromised by their prospective approach and test materials made of a crude extract; therefore, it would be insufficient to confirm the solitary effect of HA. Further study into racial variation by placebocontrolled double-blind clinical trials should be pursued to re-confirm the independent effect of HA.

Although there were limitations in the studies presented here, consuming HA moisturizes the skin. One of the factors that determines the smoothness and softness of bare skin [40] is the skin's moisture content. Because consuming HA improves the skin's moisture content, HA can improve the texture and reduce wrinkles in the skin. Although there were no significant differences between the skin texture and wrinkles in the dry skin of the HA group (Hyaluronsan HA-F, $120 \mathrm{mg} /$ day) compared with the placebo group prior to the study, consuming HA significantly improved that 2 weeks after HA was ingested

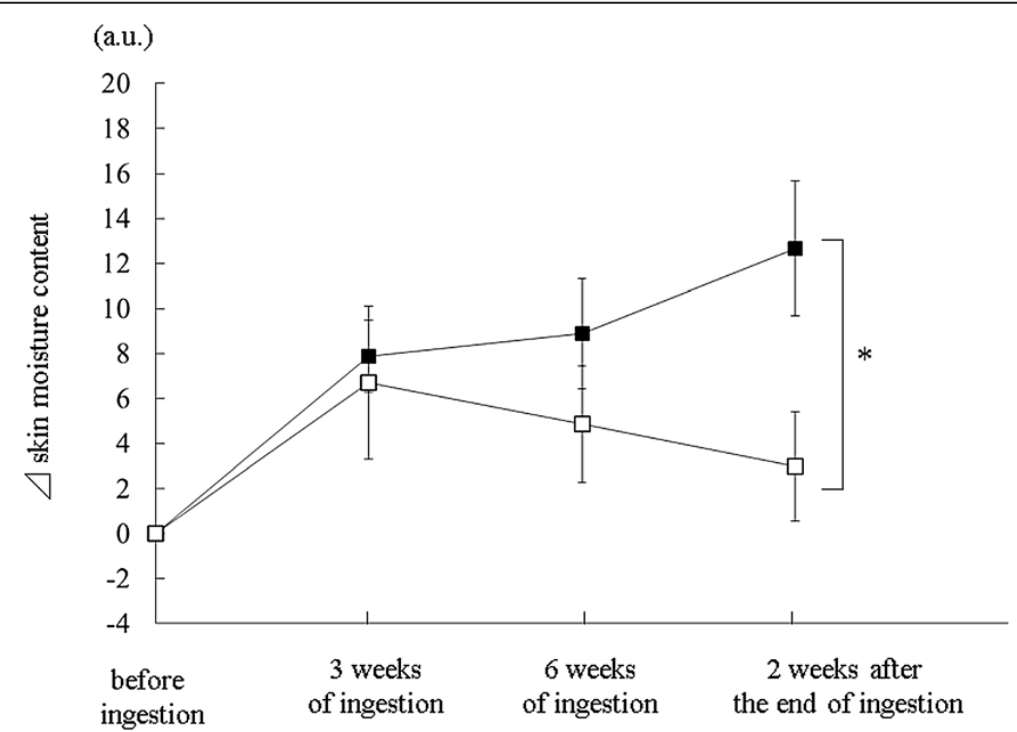

Figure 3 Skin moisture content is changed by HA (MW: $3 \times 10^{5}$ ) ingestion or placebo. 42 female subjects were randomly divided into two groups (HA group, $n=20$; subjects placebo group, $n=22$ ) to minimize the inter-group differences in skin moisture content and age. The skin moisture content at the cheeks were measured with a Corneometer ${ }^{\circledR} \mathrm{CM} 825$ before the ingestion, after 3 and 6 weeks of the ingestion, and 2 weeks after the end of ingestion. Variations in the skin moisture content relative to baseline level are shown. indicates HA; $\square$ indicates placebo. An unpaired $t$-test was used to compare the groups. Data are presented as mean \pm S.E. Asterisks indicate a statistically significant difference, ${ }^{*} p<0.05$. 
[15]. In addition, oral ingestion of HA (Hyabest ${ }^{\oplus}(\mathrm{S})$ LF-P) improved the skin's moisture content in an ultraviolet irradiated skin model [41,42]. Features of skin aging, such as wrinkle formation, occur primarily because of irradiating ultraviolet rays from sunlight; thus, HA can also be expected to have anti-aging effects, such as improving skin texture and reducing wrinkles.

Furthermore, dry skin causes itching in patients with atopic dermatitis and senile xerosis. Thus, consuming HA moisturizes the skin and also reduces the itching that is associated with dry skin.

\section{Pharmacokinetics of ingested hyaluronan}

Polysaccharides can be degraded with digestive enzymes (e.g., starches) into monosaccharides or oligosaccharides, and these degraded fragments can then be absorbed. However, there are no digestive enzymes that degrade HA; thus, there is a possibility that HA is not degraded or absorbed in the body. However, several reports show evidence for the uptake and distribution of HA into the tissues (Figure 4). In the oral administration test of radioactively labeled, high MW HA (MW: $1 \times 10^{6}$ ) to rats, approximately $90 \%$ of ingested HA was absorbed into the body and used by the body $[43,44]$. Subsequently, $80 \%$ of absorbed HA metabolites are excreted through urine and exhalation, and then decomposed and absorbed to utilize the source of energy. In contrast, the rest $10 \% \mathrm{HA}$ metabolites remain in the body after utilization. Furthermore, approximately 10\%, which was not absorbed into the body, were egested in the feces (in the orally ingested form). In addition, radioactively labeled, high- and low-MW HA (MW: $1 \times 10^{6}$ and $1 \times 10^{5}$, respectively) accumulated in skin tissue.
Ingested HA is believed to be absorbed by the intestinal route. The intestinal permeability of low MW HA was confirmed by cultured monolayers of human intestinal Caco-2 cells. Low MW HA was primarily permeated through the Caco- 2 cell monolayer via the paracellular pathway and this permeation increased inversely with the molecular size of HA [45]. In addition, orally administered HA was decomposed into low molecules by intestinal bacteria in mice [46]. Bacteroides stercoris HJ-15, which potently degrades glycosaminoglycan [47], and bacteria such as Staphylococcus aureus [48] and Clostridium perfringens [49], which produce hyaluronidases, were found in the human intestine. Thus, in humans, consumed HA is also degraded by intestinal bacteria. Dietary fiber is a polysaccharide that is resistant to digestion and is similar to HA. It is partially degraded into short chain fatty acids such as propionic acid and butyric acid or into a monosaccharide by anaerobic fermentation of intestinal bacteria in the large intestine. Hence, ingested HA and dietary fiber can be degraded with the similar dissociation process. Therefore, high MW HA that is ingested should be degraded and absorbed by the body.

Balogh et al. showed high MW HA (MW: $1 \times 106)$ was transferred into tissues without depolymerization when rats were orally administered radioactively labeled HA [44]. Further, Balogh et al. proposed that lymphatic uptake of orally administered HA initially occurs because its radioactivity in tissues preceded its appearance in the blood. However, consumed HA detected in the lymphatic fluid has not been analyzed yet.

These reports suggest that ingested HA should reach the skin by the blood and lymphatic transport systems.

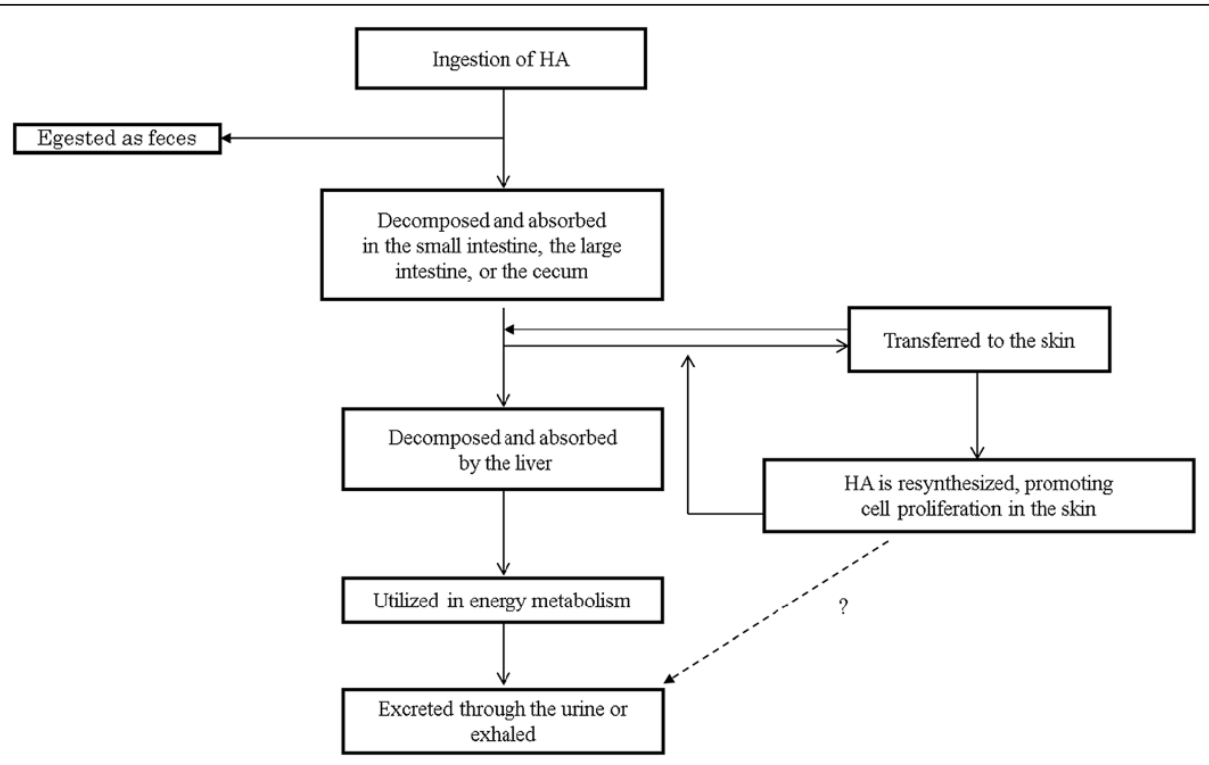

Figure 4 Metabolic pathway of ingested hyaluronan. 


\section{Table 2 Safety tests of hyaluronan}

\begin{tabular}{|c|c|c|c|c|c|c|}
\hline Test procedure & Substance & Origin & Molecular weight & Subject & Result & Reference \\
\hline $\begin{array}{l}\text { Daily oral administration } \\
\text { test for } 8 \text { weeks }\end{array}$ & HA & Chicken comb & $9 \times 10^{5}$ & Human & $\begin{array}{l}\text { No abnormalities in hematology due to } \\
240 \text { mg/kg body weight/day for } 12 \text { weeks }\end{array}$ & Sato, T. et al. (2009) [63] \\
\hline $\begin{array}{l}\text { Daily oral administration } \\
\text { test for } 1 \text { year }\end{array}$ & HA & Chicken comb & $9 \times 10^{5}$ & Human & $\begin{array}{l}\text { No abnormalities on clinical observations } \\
\text { due to oral administration of } \\
200 \mathrm{mg} / \mathrm{kg} \text { body weight/day for } 1 \text { year }\end{array}$ & Tashiro, T. et al. (2012) [7] \\
\hline \multirow[t]{7}{*}{ Single-dose toxicity test } & Sodium hyaluronate & Chicken comb & Not shown & Mouse & LD50 (mg/kg body weight) > 2400 & Nagano, K. et al. (1984) [55] \\
\hline & & & & & LD50 (mg/kg body weight) > 1200 & Nagano, K. et al. (1984) [56] \\
\hline & Sodium hyaluronate & Chicken comb & Not shown & Rat & LD50 (mg/kg body weight) > 800 & Nagano, K. et al. (1984) [55] \\
\hline & & & & & LD50 (mg/kg body weight) > 1200 & Nagano, K. et al. (1984) [56] \\
\hline & & Microbial fermentation & $16.8 \times 10^{5}$ & & LD50 (mg/kg body weight) > 200 & Morita, H. et al. (1991) [57] \\
\hline & Sodium hyaluronate & Chicken comb & Not shown & Rabbit & LD50 (mg/kg body weight) > 1000 & Nagano, K. et al. (1984) [55] \\
\hline & & & & & LD50 (mg/kg body weight) > 900 & Nagano, K. et al. (1984) [56] \\
\hline \multirow[t]{2}{*}{ Repeated-dose toxicity test } & HA & Microbial fermentation & $3 \times 10^{5}$ & rat & $\begin{array}{l}\text { No abnormalities on clinical observations } \\
\text { due to administration in doses equivalent } \\
\text { to } 0,34,235,3536 \mathrm{mg} / \mathrm{kg} \text { body weight/day. }\end{array}$ & Oe, M. et al. (2011) [58] \\
\hline & Sodium hyaluronate & Chicken comb & Not shown & & NOAEL 48 mg/kg body weight, or more & Ishihara, M. et al. (1996) [59] \\
\hline \multirow[t]{4}{*}{ Antigenicity test } & Sodium hyaluronate & Microbial fermentation & $18.8 \times 10^{5}$ & Bacteria (Ames test) & $\begin{array}{c}\text { No mutagenicities to S. typhimurium } \\
\text { (TA1535, TA1537, TA98, or TA100) or } \\
\text { E.coli (WP } 2 \text { urA) }\end{array}$ & Sugiyama, C. et al. (1991) [60] \\
\hline & & Not shown & $21.2 \times 10^{5}$ & & $\begin{array}{l}\text { No mutagenicities to S. typhimurium (TA98, } \\
\text { TA100, TA1535, or TA1537) or E.coli (2 urA) }\end{array}$ & Onishi, M. et al. (1992) [61] \\
\hline & & Chicken comb & $20.0-21.2 \times 10^{5}$ & Mouse, rat, rabbit & $\begin{array}{l}\text { No antigenicity on PCA reaction } \\
\text { in mice or guinea pigs }\end{array}$ & Takemoto, M. et al. (1992) [62] \\
\hline & & & & & $\begin{array}{l}\text { No antigenicity on active systemic } \\
\text { anaphylactic reaction in guinea pigs }\end{array}$ & \\
\hline
\end{tabular}


However, further studies need to elucidate the precise absorption mechanism of ingested HA.

\section{Mechanisms of action for the ingested hyaluronan} Consuming HA moisturizes the skin by causing the skin cells to transfer HA to the skin, despite its MW [50]. These absorption reports of digested HA reveal that partially depolymerized HA is absorbed by the gastrointestinal tract while intact HA is absorbed by the lymphatic system. Both the partially depolymerized and the fully intact HA were distributed to the skin. HA oligosaccharides (MW: $1-2 \times 10^{3}$ ) increased HA production in human fibroblasts, probably by displacing endogenous HA from the receptors [51]. In addition, low MW HA used primers when high-molecular-weight HA was synthesized in the cortical cells of the vitreous body [52]. The amount of $\mathrm{HA}$ in the skin is one of the main factors that determines the skin moisture content [53]. The metabolites of ingested HA moisturizes the skin. High MW HA (MW: $1.1 \times 10^{6}$ ) promoted cell proliferation in the manufacturing of human fibroblast populated collagen lattices [54]. This increase of the cell number suppresses the skin's water loss by filling the gaps of the skin cells and increasing the amount of HA synthesis in the skin.

The aforementioned reports suggest that both low- and high-MW HA transfer to the skin and affect the fibroblast cells to promote HA synthesis and cell proliferation, which contribute to moisturizing the skin.

\section{Safety of ingested hyaluronan}

HA is safe as a daily ingestible food. There are sufficient safety data for HA, no matter the origin or molecular weight (Table 2). Acute toxicity tests in animals reveal that oral HA ingestion results in a $\mathrm{LD}_{50}$ (lethal dose, $50 \%$ ) of $800-2400 \mathrm{mg} / \mathrm{kg}, 200-1200 \mathrm{mg} / \mathrm{kg}, 900-1000 \mathrm{mg} / \mathrm{kg}$ body weight, or more, in mice, rats, and rabbits, respectively [36-38,55-57]. In a 28-day dietary HA (Hyabest $^{\circ}(S)$ LF-P: toxicity study, rats were orally administrated HA $(0,34,235,3536 \mathrm{mg} / \mathrm{kg}$ body weight/day). The results revealed no mortalities, no clinical observation of changes in body weight, no effects on food consumption or food efficiency, no changes in organ weight, gross findings, and no alterations in clinical pathology or histopathology [58]. Another study showed a no-observed-adverse-effect level (NOAEL) of more than $48 \mathrm{mg} / \mathrm{kg}$ per day in a 90-day dietary toxicity study of sodium hyaluronate [59]. Further, Ames tests revealed that no mutagenicity occurred in Salmonella typhimurium or Escherichia coli tester strains $(\leq 1000 \mu \mathrm{g} /$ plate HA) [60,61].

Furthermore, sodium hyaluronate was found to be negative in antigenicity tests in both mouse-rat and guinea pig-guinea pig systems of passive cutaneous anaphylaxis (PCA) reaction [62]. The active systemic anaphylaxis reaction induced by HA was found to be negative in the guinea pig used in the guinea pig-guinea pig system of PCA reaction [62].

The safety of ingested HA was validated in human clinical trials (unpublished data). In a randomized, doubleblind, placebo-controlled study, human subjects (average age \pm S.E.; $30.2 \pm 9.7$ ) that had rough and chronically dry skin received low or high doses of HA (Hyaluronsan HA-F, $120 \mathrm{mg} /$ day, $\mathrm{n}=17$; $360 \mathrm{mg} /$ day, $\mathrm{n}=17$, respectively) or a placebo, crystalline cellulose $(n=18)$ for 4 weeks. The effects of ingested HA on the human body were examined by the blood test. Significant changes were observed in parts of blood components compared before ingestion in all groups; however, these changes were within normal limits and were not considered a medical abnormality. Further, hematological abnormalities did not occur in human subjects who received $240 \mathrm{mg} /$ day and $200 \mathrm{mg} /$ day of HA (Hyabest ${ }^{\circ}(\mathrm{J}): \mathrm{MW} 9 \times 10^{5}$, Kewpie Co., Tokyo) for 12 weeks or 12 months, respectively [7,63].

These clinical trials show that HA is a safe dietary supplement that does not harm the body.

\section{Conclusion}

The reduction of HA in the skin by intrinsic and extrinsic factors such as aging and ultraviolet radiation, smoking and air pollutants induce dryness in the skin. However, daily HA supplements can moisturize the skin because the metabolites of HA increases the skin moisture content by having an effect on the skin cells. Thus, consuming HA affects skin cell and improves dry skin physiologically. This review shows that consuming HA moisturizes the skin and employing HA as a dietary supplement makes the skin healthy. We believe that countries worldwide will benefit from this review and consume HA to alleviate dry skin.

\section{Abbreviations \\ HA: Hyaluronan; HAS: Hyaluronan synthases; NOAEL: No observed adverse effect level; MW: Molecular weight; LD L $_{50}$ : Lethal dose 50\%; PCA: Passive cutaneous anaphylaxis.}

Competing interests

The authors declare that they have no competing interests.

Authors' contributions

All authors managed the literature searches, formulated the hypothesis and contributed to the discussion and conclusions. CK mainly wrote the manuscript. All authors read and approved the final manuscript.

\section{Author details}

${ }^{1}$ R\&D Division, Kewpie Corporation, 2-5-7, Sengawa-cho, Chofu-shi, Tokyo, Japan. 2Department of Dermatology, Toho University Ohashi Medical Center, 2-17-6 Ohashi, Meguro-ku, Tokyo, Japan.

Received: 26 March 2014 Accepted: 8 July 2014

Published: 11 July 2014

\section{References}

1. Meyer K, Palmer JW: The polysaccharide of the vitreous humor. J Biol Chem 1943, 107:629-634. 
2. Laurent TC, Fraser JR: Hyaluronan. FASEB J 1992, 6:2397-2404.

3. Simpson RM, Meran S, Thomas D, Stephens P, Bowen T, Steadman R, Phillips A: Age-related changes in pericellular hyaluronan organization leads to impaired dermal fibroblast to myofibroblast differentiation. Am J Pathol 2009, 175(5):1915-1928.

4. Holmes MW, Bayliss MT, Muir H: Hyaluronic acid in human articular cartilage. Age-related changes in content and size Biochem J 1988, 250(2):435-441.

5. Uitto J: Understanding premature skin aging. N Engl J Med 1997 337(20):1463-1465.

6. Kalman DS, Heimer M, Valdeon A, Schwartz H, Sheldon E: Effect of a natural extract of chicken combs with a high content of hyaluronic acid $\left(\right.$ Hyal-Joint $\left.{ }^{\oplus}\right)$ on pain relief and quality of life in subjects with knee osteoarthritis: a pilot randomized double-blind placebo-controlled trial. Nutr J 2008, 7:3. doi:10.1186/1475-2891-7-3.

7. Tashiro T, Seino S, Sato T, Matsuoka R, Masuda Y, Fukui N: Oral administration of polymer hyaluronic acid alleviates symptoms of knee osteoarthritis: a double-blind, placebo-controlled study over a 12-month period. ScientificWorldJournal 2012, 2012:167928. doi:10.1100/2012/167928.

8. Bucci LR, Turpin AA: Will the real hyaluronan please stand up? J App/ Nutr 2004, 54:10-33.

9. Rogers J, Harding C, Mayo A, Banks J, Rawlings A: Stratum corneum lipids: the effect of ageing and the seasons. Arch Dermatol Res 1996, 288(12):765-770.

10. Nordstrom KM, McGinley KJ, Kligman AM, Leyden JJ: Sebaceous lipids in xerosis of the skin. J Cutan Aging Cosmet Dermatol 1989, 1:29-33.

11. Sunwoo Y, Chou C, Takeshita J, Murakami M, Tochihara Y: Physiological and subjective responses to low relative humidity. J Physiol Anthropol 2006 25(1):7-14.

12. Sunwoo Y, Chou C, Takeshita J, Murakami M, Tochihara Y: Physiological and subjective responses to low relative humidity in young and elderly men. J Physiol Anthropol 2006, 25(3):229-238.

13. Tupker RA, Bunte EE, Fidler V, Wiechers JW, Coenraads PJ: Irritancy ranking of anionic detergents using one-time occlusive, repeated occlusive and repeated open tests. Contact Dermatitis 1999, 40(6):316-322.

14. Hashizume H: Skin aging and dry skin. J Dermatol 2004, 31:603-609.

15. Kajimoto O, Odanaka W, Sakamoto W, Yoshida K, Takahashi T: Clinical effect of hyaluronic acid diet for Dry skin - objective evaluation with microscopic skin surface analyzer-. J New Rem \& Clin 2001, 50(5):548-560 (in Japanese).

16. Sato T, Sakamoto W, Odanaka W, Yoshida K, Urushibata O: Clinical effects of hyaluronic acid diet for Dry and rough skin. Aesthe Derma 2002 12:109-120 (in Japanese)

17. Sato T, Yoshida T, Kanemitsu T, Yoshida K, Hasegawa M, Urushibata O: Clinical effects of hyaluronic acid diet for moisture content of dry skin. Aesthe Derma 2007, 17:33-39 (in Japanese).

18. Yoshida T, Kanemitsu T, Narabe O, Tobita M: Improvement of dry skin by a food containing hyaluronic acids derived from microbial fermentation. J New Rem \& Clin 2009, 58(8):143-155 (in Japanese).

19. Terashita T, Shirasaka N, Kusuda M, Wakayama S: Chemical composition of low-molecular weight hyaluronic acid from (chicken) and maintaining the moisture effect of ski by a clinical test. Memoirs of the Faculty of Agri of Kinki University 2011, 44:1-8 (in Japanese).

20. Schwartz SR, Park J: Ingestion of BioCell Collagen ( $\left.{ }^{\oplus}\right)$, a novel hydrolyzed chicken sternal cartilage extract; enhanced blood microcirculation and reduced facial aging signs. Clin Interv Aging 2012, 7:267-273.

21. Fraser JR, Laurent TC, Laurent UB: Hyaluronan: its nature, distribution, functions and turnover. J Intern Med 1997, 242(1):27-33.

22. Reed RK, Lilja K, Laurent TC: Hyaluronan in the rat with special reference to the skin. Acta Physiol Scand 1988, 134:405-411.

23. Laurent UBG, Dahl LB, Reed RK: Catabolism of hyaluronan in rabbit skin takes place locally, in lymph nodes and liver. Exp Physiol 1991, 76:695-703.

24. Sayo T, Sugiyama Y, Takahashi Y, Ozawa N, Sakai S, Ishikawa O, Tamura M, Inoue S: Hyaluronan synthase 3 regulates hyaluronan synthesis in cultured human keratinocytes. J Invest Dermatol 2002, 118(1):43-48.

25. Röck K, Grandoch M, Majora M, Krutmann J, Fischer JW: Collagen fragments inhibit hyaluronan synthesis in skin fibroblasts in response to ultraviolet B (UVB): new insights into mechanisms of matrix remodeling J Biol Chem 2011, 286(20):18268-18276. doi:10.1074/jbc.M110.201665.

26. Reed RK, Lilja K, Laurent TC: Acta Hyaluronan in the rat with special reference to the skin. Physiol Scand 1988, 134(3):405-411.

27. Brecht M, Mayer U, Schlosser E, Prehm P: Increased hyaluronate synthesis is required for ${ }^{\circledR}$ broblast detachment and mitosis. Biochem J 1986, 239:445-450.
28. Chen WY, Grant ME, Schor AM, Schor SL: Differences between adult and foetal ${ }^{\circledR}$ broblasts in the regulation of hyaluronate synthesis: correlation with migratory activity. J Cell Sci 1989, 94:577-584

29. Wells AF, Lundin AÊ, MichaeĖlsson G: Histochemical localization of hyaluronan in psoriasis, allergic contact dermatitis and normal skin. Acta Derm Venereol 1991, 71:232-238.

30. Stern R, Maibach HI: Hyaluronan in skin: aspects of aging and its pharmacologic modulation. Clin Dermatol 2008, 26:106-122.

31. Stern R, Asari AA, Sugahara KN: Hyaluronan fragments: an information-rich system. Eur J Cell Biol 2006, 85(8):699-715.

32. Kogan G, Soltes L, Stern R, Gemeiner P: Hyaluronic acid: a natural biopolymer witha broad range of biomedical and industrial applications. Biotechnol Lett 2007, 29:17-25.

33. Balazs EA, Denlinger JL: Clinical uses of hyaluronan. Ciba Found Symp 1989, 143:265-280.

34. Higashide T, Sugiyama K: Use of viscoelastic substance in ophthalmic surgery - focus on sodium hyaluronate. Clin Ophthalmol 2008, 2(1):21-30.

35. Necas J, Bartosikova L, Brauner P, Kolar J: Hyaluronic acid (hyaluronan): a review. Vet Med 2008, 53(8):397-411.

36. Nishimura K, Uchino S, Sato I: The preventive effect of water soluble dietary fiber hyaluronic acid on the detrioration of walleye Pollack muscle proteins during storage at $-20^{\circ} \mathrm{C}$. J Jpn Assoc Diet Fiber Res 2000, 4(2):67-70 (in Japanese).

37. Yamamoto H, Nishimura K, Sato l: Effect of hyaluronic acid on the mechanical properties and water-holding capacity of Gel-type protein foods. Japan society of Home Economics 2003, 54(7):583-589.

38. Fuji Keizai Co., Ltd: H.B Foods Marketing Handbook 2014. Vol.3. Tokyo, Japan: 2014:110-111. in Japanese.

39. Ohno $M$, lida $H$, Hirose $O$, Kojima $H$, Hasegawa $K$ : The influence of room temperature, humidity, season, and facial cleansing with soap on skin physiological function. The Japanese Journal of Dermatology 1987 97(8):953-964 (in Japanese)

40. Blank $\mathrm{H}$ : Factors which influence the water content of the stratum corneum. J Invest Dermatol 1952, 18:433-440.

41. Kawada C, Furuki S, Kurihara H, Kimura M, Kanemitsu T, Watanabe M, Nomura Y: Orally administrated hyaluronic acid improves photoaged skin in hairless mice. Jpn Pharmacol Ther 2013, 41(8):773-778 (in Japanese).

42. Kawada C, Furuki S, Kurihara H, Kimura M, Kanemitsu T, Watanabe M, Nomura Y: Orally administrated hyaluronic acid improves photoaged skin in hairless mice. Jpn Pharmacol Ther 2013, 41(7):697-704 (in Japanese).

43. Sato T: Hyaluronic acid. JSMUFF 2005, 2(6):323-328 (in Japanese).

44. Balogh L, Polyak A, Mathe D, Kiraly R, Thuroczy J, Terez M, Janoki G, Ting Y, Bucci LR, Schauss AG: Absorption, uptake and tissue affinity of highmolecular-weight hyaluronan after oral administration in rats and dogs. J Agric Food Chem 2008, 56(22):10582-10593.

45. Hisada N, Satsu H, Mori A, Totsuka M, Kamei J, Nozawa T, Shimizu M: Low-molecular-weight hyaluronan permeates through human intestinal Caco-2 cell monolayers via the paracellular pathway. Biosci Biotechnol Biochem 2008, 72(4):1111-1114.

46. Lee B, Lee JH, Lee HS, Bae EA, Huh CS, Ahn YT, Kim DH: Glycosaminoglycan degradation-inhibitory lactic acid bacteria ameliorate 2,4,6-trinitrobenzenesulfonic acid-induced colitis in mice. J Microbiol Biotechnol 2009, 19(6):616-621.

47. Ahn MY, Shin KH, Kim DH, Jung EA, Toida T, Linhardt RJ, Kim YS: Characterization of a Bacteroides species from human intestine that degrades glycosaminoglycans. Can J Microbiol 1998, 44:423-429.

48. Jones RC, Deck J, Edmondson RD, Hart ME: Relative quantitative comparisons of the extracellular protein profiles of Staphylococcus aureus UAMS- 1 and its sarA, agr, and sarA agr regulatory mutants using one-dimensional polyacrylamide gel electrophoresis and nanocapillary liquid chromatography coupled with tandem mass spectrometry. J Bacteriol 2008, 190(15):5265-5278.

49. Shimizu T, Ohtani K, Hirakawa H, Ohshima K, Yamashita A, Shiba T, Ogasawara N, Hattori M, Kuhara S, Hayashi H: Complete genome sequence of Clostridium perfringens, an anaerobic flesh-eater. Proc Natl Acad SCi U S A 2002, 99(2):996-1001.

50. Laznicek M, Laznickova A, Cozikova D, Velebny V: Preclinical pharmacokinetics of radiolabelled hyaluronan. Pharmacol Rep 2012, 64(2):428-437.

51. Lüke HJ, Prehm P: Synthesis and shedding of hyaluronan from plasma membranes of human fibroblasts and metastatic and non-metastatic melanoma cells. Biochem J 1999, 343(1):71-75. 
52. Osterlin $\mathrm{SE}$, Jacobson B: The synthesis of hyaluronic acid in vitreous. I. Soluble and particulate transferases in hyalocytes. Exp Eye Res 1968, 7(4):497-510.

53. Oh JH, Kim YK, Jung JY, Shin JE, Kim KH, Cho KH, Eun HC, Chung JH: Intrinsic aging- and photoaging-dependent level changes of glycosaminoglycans and their correlation with water content in human skin. J Dermatol Sci 2011, 62(3):192-201.

54. Greco RM, locono JA, Ehrlich HP: Hyaluronic acid stimulates human fibroblast proliferation within a collagen matrix. J Cell Physiol 1998, 177(3):465-473.

55. Nagano K, Goto S, Okabe R, Yamaguchi T: Acute toxicity tests of sodium hyaluronate(SPH). Jpn Pharmacol Ther 1984, 12(12):37-45 (in Japanese).

56. Nagano K, Goto S, Okabe R, Sato S, Yamaguchi T: Acute toxicity test of sodium hyaluronate(SPH) in mice, rats and rabbits. Pharmacometrics 1984, 28(6):1013-1019 (in Japanese).

57. Morita H, Kawakami Y, Shimomura K, Sunaga M: Acute toxicity study of sodium hyaluronate(SL-1010) in rats and dogs. Jpn Pharmacol Ther 1991, 19(1):13-18 (in Japanese).

58. Oe M, Yoshida T, Kanemitsu T, Matsuoka R, Masuda Y: Repeated 28-day oral toxicological study of hyaluronic acid in rats. Pharmacometrics 2011 81(1/2):11-21 (in Japanese).

59. Ishihara M, Inouye T, Ishihara Y, Sakata T, Ichikawa A, Funahashi N, Kato T, Takahashi T, Horie K: Toxicity study on sodium hyaluronate (Na-HA) in rats by repeated oral administration for 90 days followedby a 28-Day recovery study. Pharmacometrics 1996, 51(2):97-113 (in Japanese).

60. Sugiyama C, Yagame O: Mutagenicity tests on sodium hyaluronate(SL1010)(I)-reverse mutation test in bacteria-. Jpn Pharmacol Ther 1991, 19(1):177-181 (in Japanese).

61. Onishi M, Nagata T, Saigou T, Samezima S, Nagata R: Mutagenicity Studies of Sodium Hyaluronate(SH). Jpn Pharmacol Ther 1992, 20(3):65-72 (in Japanese).

62. Takemoto M, Ohzune Y, Asahi K: Antigenicity test of sodium hyaluronate (SH). Jpn Pharmacol Ther 1992, 20(3):59-64 (in Japanese).

63. Sato T, Iwaso H: An Effectiveness Study of Hyaluronic acid [Hyabest $\left.{ }^{\oplus}(\mathrm{J})\right]$ in the Treatment of Osteoarthritis of the Knee on the Patients in the United States. J New Rem \& Clin 2009, 58(3):249-256.

doi:10.1186/1475-2891-13-70

Cite this article as: Kawada et al.: Ingested hyaluronan moisturizes dry skin. Nutrition Journal 2014 13:70.

\section{Submit your next manuscript to BioMed Central and take full advantage of:}

- Convenient online submission

- Thorough peer review

- No space constraints or color figure charges

- Immediate publication on acceptance

- Inclusion in PubMed, CAS, Scopus and Google Scholar

- Research which is freely available for redistribution 